\title{
Licofelone Attenuates LPS-induced Depressive-like Behavior in Mice: A Possible Role for Nitric Oxide
}

Seyyedeh Elaheh Mousavi ${ }^{a}$, Pegah Saberi ${ }^{\mathrm{b}}$, Naeemeh Ghasemkhanic ${ }^{c}$, Nahid Fakhraeic, Rezvan Mokhtari ${ }^{\mathrm{b}}$, Ahmad Reza Dehpour ${ }^{\mathrm{a}, \mathrm{c}, \mathrm{d}}$

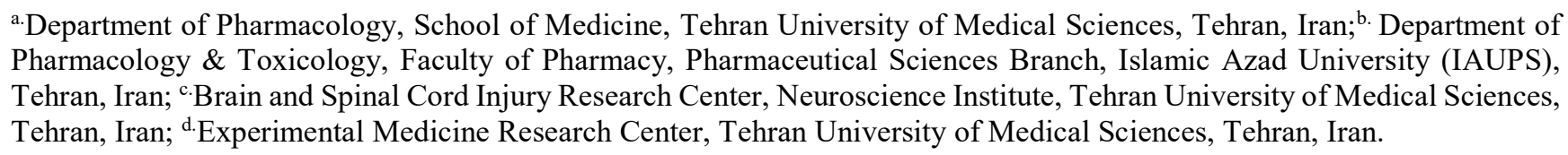

Received, January 20, 2018; Revised, February 18, 2018; Accepted, May 9, 2018; Published, May 10, 2018.

\begin{abstract}
PURPOSE: Licofelone, a dual cyclooxygenase/5-lipoxygenase inhibitor, possesses antioxidant, antiapoptotic, neuroprotective, and anti-inflammatory properties. The aim of the present study was to investigate the effect of licofelone on lipopolysaccharide (LPS)-induced depression in a mouse model and also a possible role for NO. METHODS: To elucidate role of NO on this effect of licofelone ( 5 and $20 \mathrm{mg} / \mathrm{kg}$, i.p.), L-NAME, a nonspecific NO synthase (NOS) inhibitor; aminoguanidine (AG), a specific inducible NOS (iNOS) inhibitor; 7nitroindazole (7-NI) a preferential neuronal NOS inhibitor (nNOS) and; L-arginine (L-Arg), as a NO donor, were used. The animal's behaviors were evaluated employing forced swimming test (FST), tail suspension test (TST) and open field test (OFT). RESULTS: LPS $(0.83 \mathrm{mg} / \mathrm{kg}$, i.p.) induced depressive-like behavior increasing immobility time in FST and TST. Conversely, licofelone $(20 \mathrm{mg} / \mathrm{kg}$ i.p.) reversed the depressive effect of LPS and lowered the immobility time in FST and TST. On the other hand, pretreatment with L-Arg also reversed the antidepressant-like effect of licofelone $(20 \mathrm{mg} / \mathrm{kg})$ in FST and TST. On the other hand, L-NAME (10 and 30 $\mathrm{mg} / \mathrm{kg}), \mathrm{AG}(50$ and $100 \mathrm{mg} / \mathrm{kg})$ and 7-NI $(60 \mathrm{mg} / \mathrm{kg})$ could potentiate licofelone $(5 \mathrm{mg} / \mathrm{kg})$ and lowered the immobility duration. CONCLUSIONS: NO down-regulation possibly through iNOS and nNOS inhibition may involve in the antidepressant property of licofelone.
\end{abstract}

This article is open to POST-PUBLICATION REVIEW. Registered readers (see "For Readers") may comment by clicking on ABSTRACT on the issue's contents page.

\section{INTRODUCTION}

Oxidative arachidonic acid (AA) metabolism is considered a major feature in neuroinflammation (1). Following its release from the cell membrane by activated neuronal phospholipase A2 (PLA2), AA is metabolized through cyclooxygenase (COX) and 5lipoxygenase (5-LOX) into the prostaglandins (PGs) and leukotrienes (LTs), respectively (2). Neural and non-neural mammalians' cells and tissues express several distinct forms of COX and LOX under normal or stimulated conditions (3). These enzymes are involved in initiation, maintenance, and modulation of inflammatory processes, and also aging, apoptosis, platelet aggregation, oxidative stress and synaptic activity (3). Neuroprotective potential of COX-2 inhibitors and 5-LOX inhibitors has been documented in different experimental model of neurotoxicity $(4,5)$.
In animal studies, administration of exogenous pro-inflammatory cytokines or a cytokine inducer such as lipopolysaccharide (LPS), triggers depressive-like behavior in rodents, leading to enhanced immobility in the forced swimming (FST) and tail suspension (TST) tests, decreased consumption of a sweetened solution and suppression of sexual behavior, which can be attenuated by antidepressant treatments $(6,7)$. Based on the neuroinflammation hypothesis of depression, LPS-received mice are extensively used to evaluate the underlying mechanisms of depression $(8,9)$. Licofelone ([2, 2-dimethyl-6-(4-chlorophenyl)-7phenyl-2, 3, dihydro-1H-pyrrolizine-5-yl]-acetic

Corresponding Author: Prof. Ahmad Reza Dehpour, Address: Department of Pharmacology, School of Medicine, Tehran University of Medical Sciences, Tehran, Ira. Email: dehpour@yahoo.com; dehpour@sina.tums.ac.ir 
acid) is a substrate analogue of AA and consequently inhibits 5-LOX, COX-1 and COX-2, reducing production of eicosanoid (10). Due to its conformational similarity to AA, licofelone is able to bind the active sites of COX and 5-LOX, therefore blocking their catalytic action (11). Licofelone is a representative of the so-called 'dual inhibitors' of the COX and 5-LOX pathway that have shown to be efficient in several preclinical animal models of inflammation and clinical studies on human subjects (12). Licofelone inhibits prostaglandins synthesis as well as leukotrienes, responsible for the various behavioral (anxiety or depression like behaviors) and biochemical alterations (13).

Licofelone has good oral bioavailability, long half-life $(11 \mathrm{~h})$ with no genotoxicity $(13,14)$. Licofelone has been specifically developed to overcome the gastrointestinal (GI) side-effects associated to non-steroidal anti-inflammatory drugs (NSAIDs) (16). Experimental reports propose that licofelone holds neuroprotective, anti-inflammatory, analgesic, antipyretic, and anti-platelet activities (14, $13,17)$, antioxidant and antiapoptotic capacity $(18$, 19).

It has been shown that licofelone may have a potential therapeutic effect on neurodegenerative disorders correlated with cognitive impairment in the animal model of Alzheimer's disease (AD) by modulation of neuroinflammatory markers (20). Further, chronic licofelone (5 and $10 \mathrm{mg} / \mathrm{kg}$, p.o.) and minocycline treatments significantly attenuated behavioral alterations, oxidative damage and restored mitochondrial enzyme complex activities, whereas combination of licofelone $(5 \mathrm{mg} / \mathrm{kg})$ with minocycline $(50 \mathrm{mg} / \mathrm{kg})$ profoundly potentiated their protective effect (21). The neuroprotective activities of licofelone has been highlighted $(17,22)$, which was attributed due to its anti-inflammatory, antiapoptotic, anti-microglial and anti-oxidant properties (16, 13, 23). Licofelone modulates neuroinflammation and attenuates mechanical hypersensitivity in the chronic phase of spinal cord Injury. Long-term treatment of chronically injured rats with chronic licofelone $(50 \mathrm{mg} / \mathrm{kg}$, p.o.) elevated levels of endogenous anti-oxidant and antiinflammatory metabolites within the lesion site (24). Another COX/LOX inhibitor, BW755C, revealed protective effects in an epilepsy model and attenuated the brain damage in rats (25).

Several mechanisms have been suggested for protective effects of COX or LOX inhibitors in the central nervous system (CNS). Among these pathways, nitric oxide (NO) has always been the focus of many researches $(26,27)$. NO, a retrograde intracellular second messenger with a very concise half-life is an endogenous modulator of neuronal function (28). NO is synthesized from L-arginine (LArg) by specific subtypes of nitric oxide synthases (NOSs). NOSs are classified to distinct isoforms based on the location of expression and cell type. These isoforms include: calcium/calmodulindependent which contain endothelial-derived NOS (eNOS) or neuronal-derived NOS (nNOS), and calcium/calmodulinin dependent which contain cytokine-inducible NOS (iNOS) $(29,30)$. Various studies propose that both neuronal and inducible isoforms of NOS involve in various crucial brain processes $(31,32)$. NO may modulate COX activity and employ COX enzymes as mediators of pathophysiological responses of NO. Additionally, products of the COX pathway may inhibit or enhance NO release (33). The activation of COX-1 by NO may be correlated with the NO effect on glutathione metabolism (34). The NO effect on activation of COX-2 is debated. It has reported that $\mathrm{NO}$ activated COX-1, nonetheless; inhibited COX-2- derived prostaglandin production (35), on the other hand; another studies hypothesized that COX-2 activation caused up-regulation of $\mathrm{NO}(33,36)$.

Regarding the neuroprotective activities of licofelone in the nervous system disorders and the functional interactions of COX and/or LOX enzymes with NO signaling pathway, the present study aims to investigate acute effects of licofelone as a dual COX/LOX inhibitor on depression susceptibility via LPS-induced depression-like behavior for the first time in a mouse model and examine the probable role of NO on antidepressant-like effect of licofelone. In this regards, specific and non-specific NOS inhibiters as well as a NO precursor are employed. Thus, the aim of this study was to investigate the role of each NOS isoform and find the corresponding one.

\section{METHODS}

\section{The chemicals}

The following drugs were used in the study: lipopolysaccharide (LPS), L-arginine (L-Arg), NGL-arginine methyl ester (L-NAME), aminoguanidine (AG), and 7-nitroindazole (7-NI) were purchased from Sigma Chemical Co. (St Louis, MO). Licofelone were prepared from Tofigh Daru co., Tehran, Iran. 


\section{Animals and experimental groups}

Male NMRI mice weighing $25 \pm 5 \mathrm{~g}$ (Tehran University of Medical Sciences, Tehran, Iran) were used throughout the study. The animals were allowed free access to food and water. All the behavioral experiments were conducted during the period between 9:00 and 12:00 A.M. with normal room light (12 $\mathrm{h}$ regular light/dark cycle) and temperature $\left(22 \pm 1{ }^{\circ} \mathrm{C}\right)$. The mice were handled as indicated in the criteria proposed by the Guide for the Care and Use of Laboratory Animals (NIH US publication, no. 23-86, revised 1985).

All other drugs were administered intraperitoneally (i.p) and the injections were in a volume of $10 \mathrm{ml} / \mathrm{kg}$ of the body weight of the mice. LPS, L-NAME, AG and L-Arg were dissolved in sterile normal saline solution ( $0.9 \%)$. Licofelone and 7-NI were suspended in a $1 \%$ aqueous solution of tween 80 . Solutions of the drugs and chemicals were always prepared fresh.

The mice were divided into 21 groups of 6 . To induce depression- like behavior, they were injected with LPS $(0.83 \mathrm{mg} / \mathrm{kg}$, i.p.) (37) and $24 \mathrm{~h}$ later the other treatments were done and behavioral tests carried out. Licofelone was administered in doses 5 and $20(\mathrm{mg} / \mathrm{kg}$, i.p), $75 \mathrm{~min}$ prior to the behavioral tests. In experiments investigating the possible role of NO pathway in the licofelone central effects, LArg, a NO purcursor; L-NAME, a non-specific NOS inhibitor; AG, a specific iNOS inhibitor; 7-NI, a preferential neuronal NO synthase inhibitor, or the vehicles were administered $15 \mathrm{~min}$ before licofelone administration. The dosages and timing of drugs administrations in the present study were based upon prior reports (38-40).

\section{Behavioral tests \\ Open-field test (OFT)}

To ensure that alterations in the duration of immobility do not arise from the changes in motor activity, the locomotor behavior of mice was assessed in an open-field box $(41,42)$. The apparatus consisted of a Plexiglass box $40 \times 60 \times 50 \mathrm{~cm}$. The box floor was divided into 12 equal squares. The animals were gently placed in the one corner of the field and the number of squares which was crossed with all paws of the animal counted manually during 6 min.

\section{Forced swimming test (FST)}

When the animals are exposed to the FST, they typically adopt an immobile posture, which is thought to reflect a state of behavioral despair or helplessness (43) and the decrease in immobility time is used as an index of antidepressant activity (44). Briefly, immediately after OFT, the mice were individually placed in an open cylindrical container (diameter $10 \mathrm{~cm}$, height $26 \mathrm{~cm}$ ) containing $20 \mathrm{~cm}$ of water at $23 \pm 1{ }^{\circ} \mathrm{C}$. The mice were allowed to swim for $6 \mathrm{~min}$. The total duration of immobility was recorded manually using stopwatches during the last $4 \mathrm{~min}$ of the total 6 min duration of the test $(45,46)$. Each mouse was judged to be immobile when it was ceased struggling and remained floating motionless in the water, making only those movements necessary to keep its head above the water.

\section{Tail suspension test (TST)}

The total duration of immobility induced by tail suspension was measured according to the method described by Steru et al., (47). Briefly, a new group of mice was acoustically and visually isolated then suspended $50 \mathrm{~cm}$ above the floor by adhesive tapes placed approximately $1 \mathrm{~cm}$ from the tip of the tail. Immobility time was recorded manually using a stopwatch during a 6 min-period (48).

\section{STATISTICAL ANALYSIS}

All data were analyzed with two-way analysis of variance for the drug interactions followed by Tukey's posttest (Graph pad prism, version 5), except for the main effect of licofelone which was performed with one-way ANOVA. Totally, A value of $\mathrm{P}<0.05$ was considered to be significant.

\section{RESULTS}

Figure 1 illustrates effects of licofelone at doses 5 and 20 (mg/kg, i.p.) in FST, TST and locomotor activity on LPS-induced depressive behavior in male mice. As can be observed, LPS at dose $0.83 \mathrm{mg} / \mathrm{kg}$ markedly enhanced the immobility measure compared with control group $[\mathrm{F}(5,28)=7.489$, $\mathrm{P}<0.01]$ in FST (Fig. 1a). On the other hand, licofelone at dose $20 \mathrm{mg} / \mathrm{kg}$, i.p. successfully lowered the immobility time of the animals compared with the corresponding LPS group [F (5, 28) $=7.489, \mathrm{P}<0.01]$.

In Fig. 1b, effect of licofelone at dose $20(\mathrm{mg} / \mathrm{kg}$, i.p.) on locomotor activity of LPS-treated animals is shown. As can be understood, no significant change is observed between the groups. 
In Fig.1c, as can be observed, LPS at dose 0.83 $\mathrm{mg} / \mathrm{kg}$ markedly enhanced the immobility measure compared with the control group $[\mathrm{F}(5,28)=4.904$, $\mathrm{P}<0.05]$ in TST. Conversely, licofelone at dose 20 $\mathrm{mg} / \mathrm{kg}$, i.p. successfully lowered the immobility time of the animals compared with the corresponding LPS group $[\mathrm{F}(5,28)=4.904, \mathrm{P}<0.05]$.

Figure 2 demonstrates effect of L-Arg (750 $\mathrm{mg} / \mathrm{kg}$ ) on antidepressant like effect of licofelone (20 $\mathrm{mg} / \mathrm{kg}$ ) in FST (Fig. 2a), TST (Fig. 2c) and locomotion in OFT (Fig. 2b). As can be observed in Fig. 2a, LPS + licofelone $20 \mathrm{mg} / \mathrm{kg}$ is significantly different from LPS group and has lower immobility measure $[\mathrm{F}(5,28)=7.489, \mathrm{P}<0.01]$. On the other hand, LPS + L-Arg $750 \mathrm{mg} / \mathrm{kg}$ + licofelone $20 \mathrm{mg} / \mathrm{kg}$ has markedly higher immobility time compared with LPS group $[\mathrm{F}(5,28)=7.489, \mathrm{P}<0.01]$. Compared with LPS + licofelone $20 \mathrm{mg} / \mathrm{kg}$, the groups LPS + L-Arg $750 \mathrm{mg} / \mathrm{kg}$, and LPS + L-Arg $750 \mathrm{mg} / \mathrm{kg}+$ licofelone $20 \mathrm{mg} / \mathrm{kg}$ spend significantly more time immobile $[\mathrm{F}(5,28)=7.489, \mathrm{P}<0.01]$ and $[\mathrm{F}(5,28)$
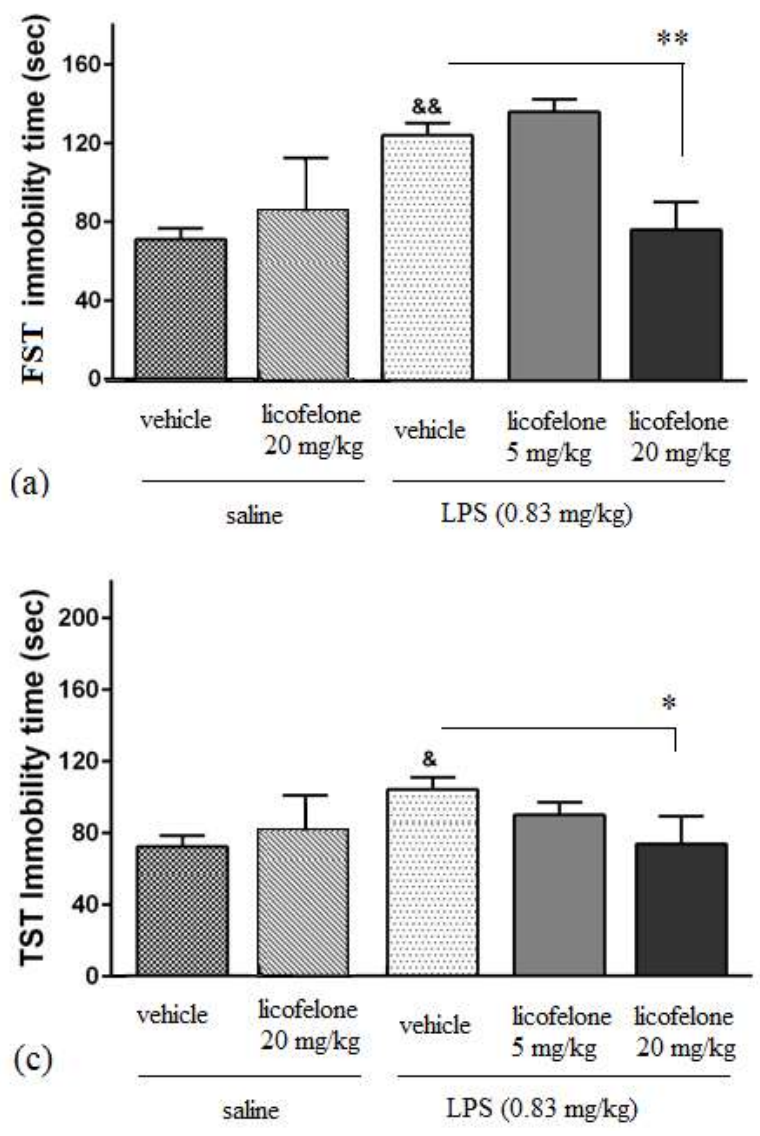

$=11.385, \mathrm{P}<0.001]$, respectively. In Fig. $2 \mathrm{c}$, immobility periods of the animals in TST regarding to LPS + licofelone $20 \mathrm{mg} / \mathrm{kg}$ is considerably lower compared with LPS group $\mathrm{P}<0.05$. In contrast, the group LPS + L-Arg $750 \mathrm{mg} / \mathrm{kg}$ + licofelone 20 $\mathrm{mg} / \mathrm{kg}$ has markedly higher immobility time compared with LPS + licofelone $20 \mathrm{mg} / \mathrm{kg}[\mathrm{F}(5,28)$ $=4.904, \mathrm{P}<0.05]$.

Figure 3 demonstrates effect of L-NAME (10 and $30 \mathrm{mg} / \mathrm{kg}$ ) on licofelone sub-effective dose (5 $\mathrm{mg} / \mathrm{kg}$ ) in FST (Fig. 3a), TST (Fig. 3c) and locomotion in OFT (Fig. 3b). As can be observed in Fig. 3a, the groups LPS + L-NAME $30 \mathrm{mg} / \mathrm{kg}+$ licofelone $5 \mathrm{mg} / \mathrm{kg}$ spend significantly less time immobile compared with LPS + licofelone $5 \mathrm{mg} / \mathrm{kg}$ $[\mathrm{F}(5,28)=4.904, \mathrm{P}<0.05]$. In Fig. 3c, immobility periods of the animals in TST regarding to LPS + licofelone $5 \mathrm{mg} / \mathrm{kg}$ is considerably lower in LPS + LNAME 10 and $30 \mathrm{mg} / \mathrm{kg}$ + licofelone $5 \mathrm{mg} / \mathrm{kg}$, [F (5, 28) $=4.904, \mathrm{P}<0.05]$.

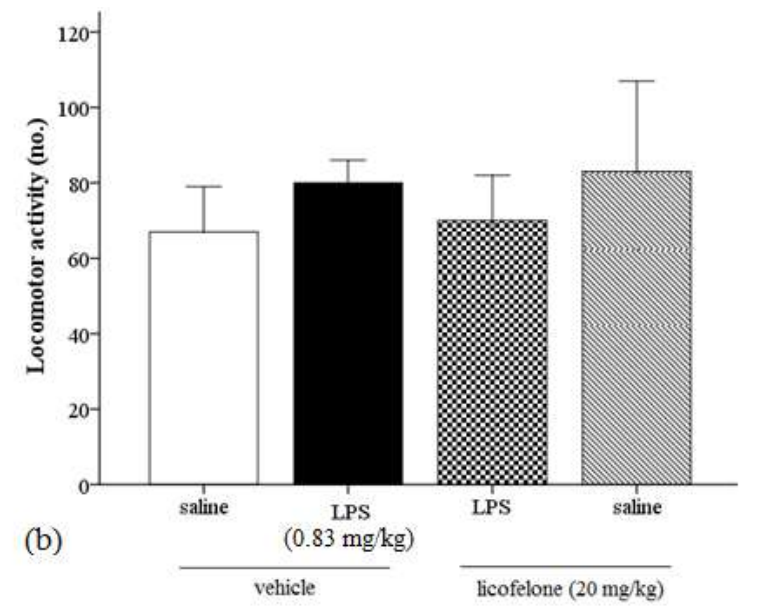

Figure 1. Effects of licofelone at doses 5 and $20 \mathrm{mg} / \mathrm{kg}$, i.p. on LPS-induced depressive effect $(0.83 \mathrm{mg} / \mathrm{kg}) \mathrm{in} \mathrm{male} \mathrm{mice}(\mathrm{n}=$ 6) on immobility time in forced-swimming test (FST) (Fig. 1a), tail suspension test (TST) (Fig. 1c) and also locomotor activity (Fig. 1b) compared with the corresponding control groups. \& $\mathrm{P}<0.05$ and $\& \& \mathrm{P}<0.01$ significantly different from saline + vehicle group. $* \mathrm{P}<0.05$ and $* * \mathrm{P}<0.01$ significantly different from LPS + vehicle group. 

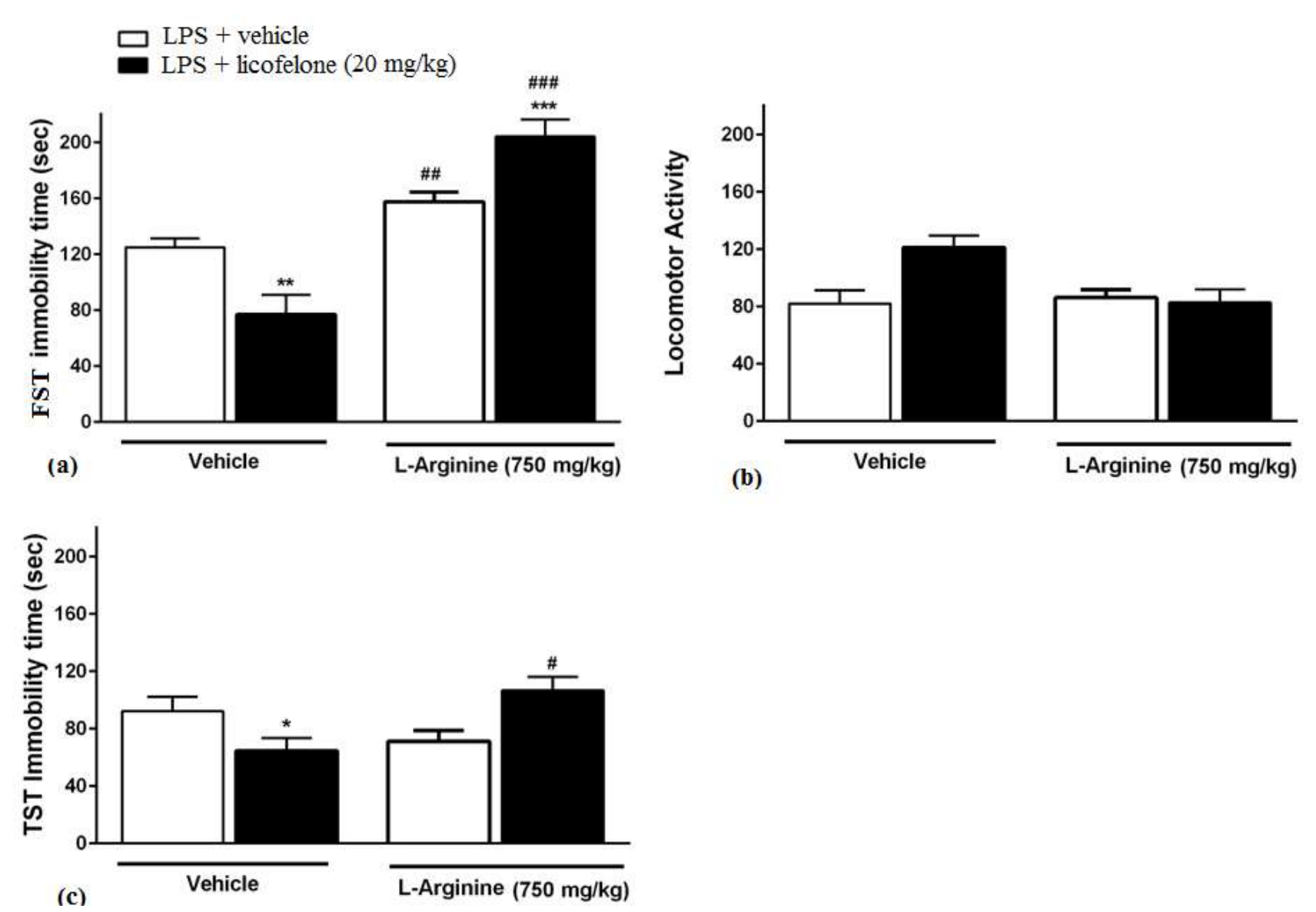

Figure 2. Effects of L-arginine (L-Arg) $750 \mathrm{mg} / \mathrm{kg}$ on antidepressant like effect of licofelone (20 mg/kg) in FST (a), TST (c) and locomotion in OFT (b). $* \mathrm{P}<0.05$, ** $\mathrm{P}<0.01$ and $* * * \mathrm{P}<0.001$ significantly different from LPS group. \# $\mathrm{P}<0.05$, \#\# $\mathrm{P}<0.01$ and \#\#\# $\mathrm{P}<0.001$ significantly different from licofelone $(20 \mathrm{mg} / \mathrm{kg})$ group. $(\mathrm{n}=6)$

Figure 4 demonstrates effect of AG (50 and 100 $\mathrm{mg} / \mathrm{kg}$ ) on sub-effective dose of licofelone $(5 \mathrm{mg} / \mathrm{kg}$ ) in F ST (Fig. 4a), TST (Fig. 4c) and locomotion in OFT (Fig. 4b). As can be observed in Fig. 4a, LPS + AG $100 \mathrm{mg} / \mathrm{kg}$ is significantly different from LPS group and has lower immobility measure $[\mathrm{F}(5,28)$ $=4.904, \mathrm{P}<0.05]$. On the other hand, LPS + AG 100 $\mathrm{mg} / \mathrm{kg}+$ licofelone $5 \mathrm{mg} / \mathrm{kg}$ has markedly lower immobility time compared with LPS + licofelone 5 $\mathrm{mg} / \mathrm{kg}$ group $[\mathrm{F}(5,28)=4.904, \mathrm{P}<0.05]$. In Fig. $4 \mathrm{c}$, immobility periods of the animals in TST, the groups LPS + AG (50 and $100 \mathrm{mg} / \mathrm{kg})+$ licofelone $5 \mathrm{mg} / \mathrm{kg}$ have markedly higher immobility time compared with LPS + licofelone $5 \mathrm{mg} / \mathrm{kg}[\mathrm{F}(5,28)=4.904$, $\mathrm{P}<0.05]$.

Figure 5 demonstrates effects of 7-NI (30 and 60 $\mathrm{mg} / \mathrm{kg}$ ) on sub-effective licofelone $(5 \mathrm{mg} / \mathrm{kg}$ ) in FST (Fig. 5a), TST (Fig. 5c) and locomotion in OFT (Fig. 5b). As can be observed in Fig. 5a, the group LPS + 7 -NI $60 \mathrm{mg} / \mathrm{kg}+$ licofelone $5 \mathrm{mg} / \mathrm{kg}$ is significantly different from LPS + licofelone $5 \mathrm{mg} / \mathrm{kg}$ group and has lower immobility measure $[\mathrm{F}(5,28)=5.924$, $\mathrm{P}<0.05]$. In Fig. 5c, immobility periods of the animals in TST regarding to LPS + 7-NI $60 \mathrm{mg} / \mathrm{kg}+$ licofelone $5 \mathrm{mg} / \mathrm{kg}$ are considerably lower compared with LPS licofelone $5 \mathrm{mg} / \mathrm{kg}$ group $[\mathrm{F}(5,28)=$ 5.924, $\mathrm{P}<0.05]$.

\section{DISCUSSION}

In the current study, we illustrated that licofelone, as a dual COX/5-LOX inhibitor, exerts an antidepressant-like property in the animal mouse model of depression. We used LPS to induce depressant-like behavior and the antidepressant effect of licofelone was demonstrated using animal behavioral tests FST and TST measuring duration of immobility as an index of depressive behavior. In this study, LPS enhanced the immobility measure of the animals, nevertheless; licofelone successfully 

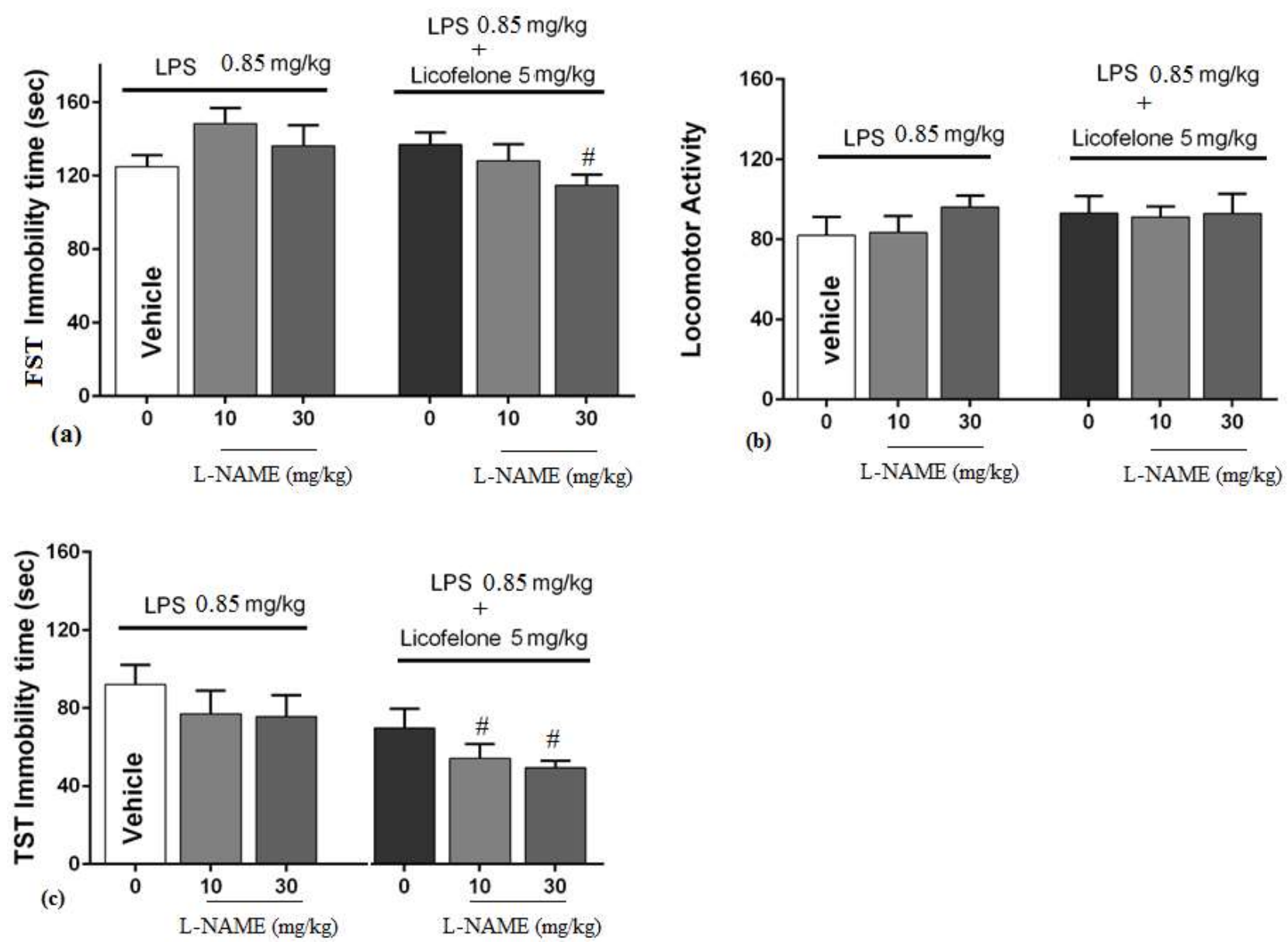

Figure 3. Effects of L-NAME (10 and $30 \mathrm{mg} / \mathrm{kg}$ ) on antidepressant like effect of licofelone sub-effective dose $(5 \mathrm{mg} / \mathrm{kg})$ in FST (Fig. 3a), TST (Fig. 3c) and locomotion in OFT (Fig. 3b). \# P $<0.05$ significantly different from LPS + licofelone (5 $\mathrm{mg} / \mathrm{kg}) .(\mathrm{n}=6)$

reversed LPS drawback and markedly decreased the immobility figure, consequently, showed antidepressant-like effect. In addition, L-Arg could block antidepressant-like activity of the effective dose of licofelone and increased the immobility time. Contrary to this, the nonselective and selective NOS inhibitors L-NAME, AG and 7-NI efficiently potentiated the sub-effective dose of licofelone and as a consequence, decrease the immobility period considerably.

Practically consistent with our experiment, recent studies revealed that $\mathrm{COX} / \mathrm{LOX}$ inhibitors such as licofelone could have central protective effects in different settings of CNS disorders (3). Licofelone had a potential therapeutic effect on a neurodegenerative disorder correlated with cognitive impairment and oxidative stress in the animal model of $\mathrm{AD}$ induced by intracerebroventricular streptozotocin. Chronic licofelone $(2.5,5$, and 10 $\mathrm{mg} / \mathrm{kg}$, p.o.) significantly decreased tumor necrosis factor-alpha (TNF- $\alpha$ ) and interleukin 1 beta (IL-1b) as the oxidative and neuroinflammatory markers in AD (20). In accordance with our study, licofelone possesses a neuroprotective effect against quinolinic acid- induced Huntington disease (HD) like symptoms in rats. Licofelone $(2.5,5$ and $10 \mathrm{mg} / \mathrm{kg}$, p.o.) treatment significantly improved body weight, locomotor activity, rotarod performance, balance beam walk performance, oxidative defense, mitochondrial enzyme complex activities and attenuated TNF- $\alpha$ level and striatal lesion (17). Likewise, the neuroprotective mechanism of licofelone $(2.5,5$ and $10 \mathrm{mg} / \mathrm{kg}$; p.o.) against 3nitropropionic acid (3-NP)-induced behavioral, biochemical and cellular alterations was demonstrated in rats which are HD-like symptoms. The beneficial effects of licofelone are probably due to its ability to suppress various neuroinflammatory and apoptosis pathways (49). 

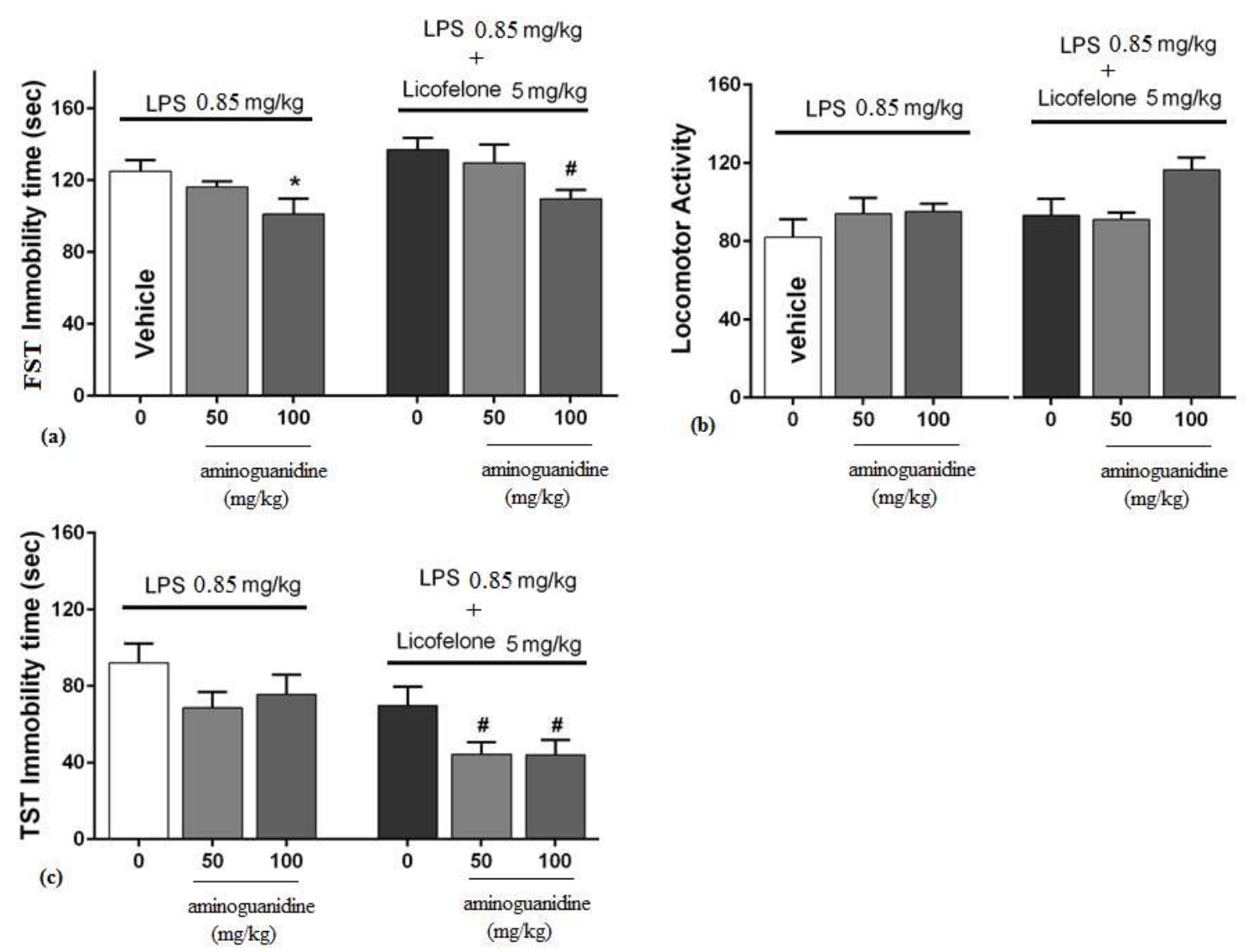

Figure 4. Effects of aminoguanidine (AG) 50 and $100 \mathrm{mg} / \mathrm{kg}$ on antidepressant like effect of sub effective dose of licofelone $(5 \mathrm{mg} / \mathrm{kg}$ ) in FST (Fig. 4a), TST (Fig. 4c) and locomotion in OFT (Fig. 4b). \# P $<0.05$ significantly different from LPS + licofelone $5 \mathrm{mg} / \mathrm{kg}$ group. $(\mathrm{n}=6)$.

It has shown that LPS activated the nuclear factor$\kappa \mathrm{B}(\mathrm{NF}-\kappa \mathrm{B})$, iNOS and cyclooxygenase-2 (COX-2) expression in the prefrontal cortex of depressed mice (50). The relation between central effect of licofelone and suppression of NO from iNOS source was demonstrated in a study. Licofelone at the dose of $10 \mathrm{mg} / \mathrm{kg}$ (i.p) revealed anticonvulsant properties through iNOS down-regulation in mice. Pretreatment L-Arg reversed this anticonvulsant effects dose dependently. However, L-NAME potentiated the anticonvulsant effects of licofelone which are completely in line with our relevant results. Nevertheless, 7-NI did not affect seizure threshold alone or in combination with licofelone. 7-NI in our study also potentiated the anticonvulsant effects of licofelone. Using non-effective doses of selective inhibitors of iNOS, AG or 1400W, significantly increased the seizure threshold when were accompanied by licofelone in low doses. These data support the involvement of $\mathrm{NO}$ as an important role player in the central neuro-protective properties of licofelone. Furthermore, it implied that downregulation of iNOS seems crucial for anticonvulsant properties of this COX/5-LOX inhibitor in seizure susceptibility (51). In agreement with our experiment, licofelone also exerted anticonvulsive effects against status epilepticus (SE) induced by lithium-pilocarpine in male Wistar rats in a dose dependent manner. Pre-treatment with L-Arg decreased the anticonvulsive effects of licofelone, whereas L-NAME potentiated the protective effects of licofelone. Pre-treatment with 7-NI did not change seizure susceptibility significantly, but coadministration of AG and licofelone exerted anticonvulsive effects. These data suggested that the NO pathway especially iNOS contributes to the anticonvulsive effects of licofelone (52). 

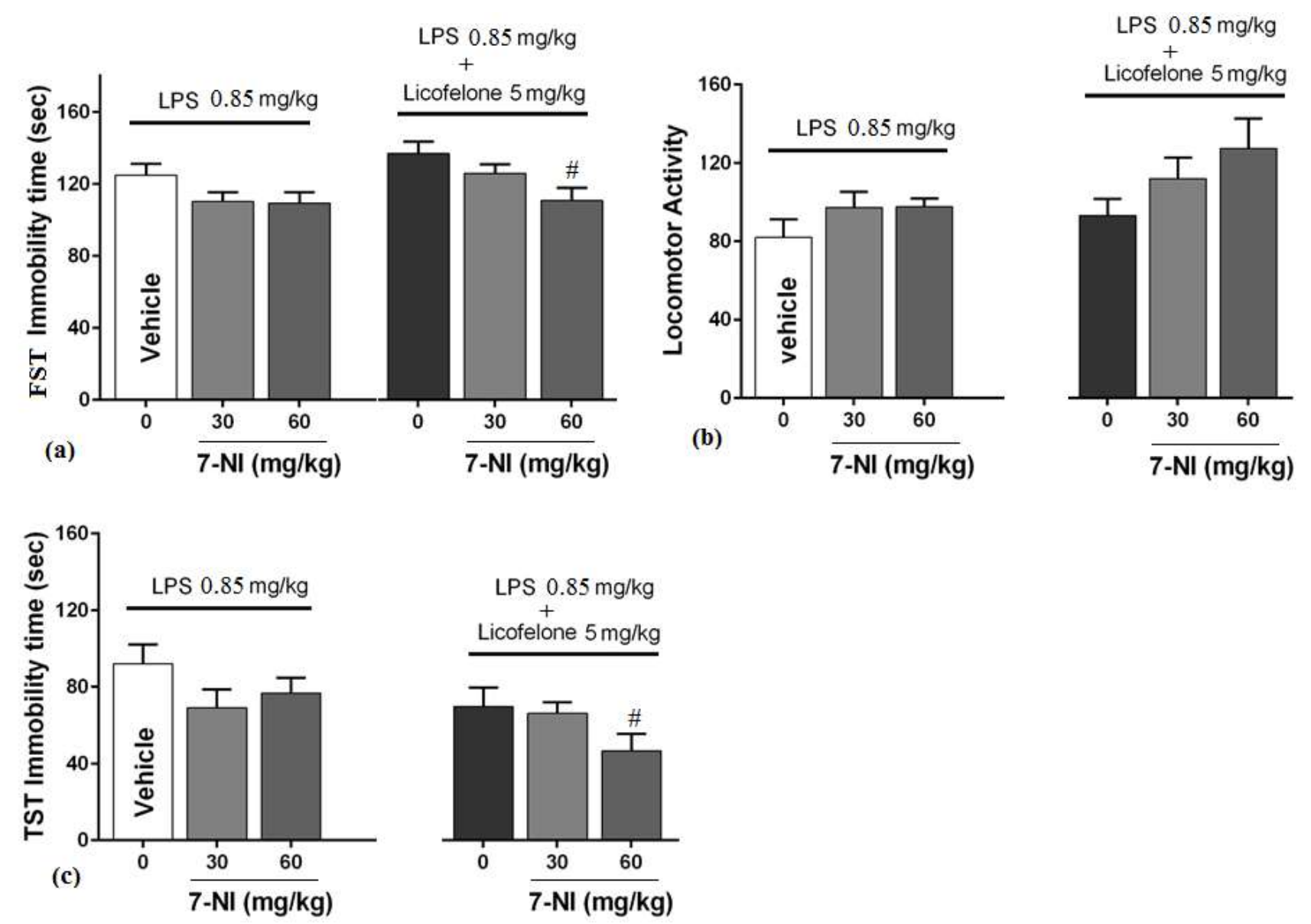

Figure 5. Effects of 7-nitroindazole (7-NI) 30 and $60 \mathrm{mg} / \mathrm{kg}$ on antidepressant like effect of licofelone (5 mg/kg) in FST (Fig. 5a), TST (Fig. 5c) and locomotion in OFT (Fig. 5b). \# $\mathrm{P}<0.05$ significantly different from LPS + licofelone $5 \mathrm{mg} / \mathrm{kg}$ group. $(n=6)$

On the whole, our experiments showed that NO system and especially down regulation of iNOS are probably involved in this neuroprotective effect of licofelone in the current inflammatory animal model of depression. These data support excess of $\mathrm{NO}$ as an important role player in depressant-like effect of LPS. Furthermore, it implies that down-regulation of NOS especially iNOS appears crucial for development of antidepressant-like property of this COX/5-LOX inhibitor in depression susceptibility. Moreover, licofelone may exert this effect through its anti-inflammatory property as well. Further, these findings may indicate a side effect of licofelone with drugs which modulate NO concentration including sodium nitroprusside (SNP) and organic nitrates. Nevertheless, complimentary studies will be needed to clarify and strengthen the role of NO system pathways in licofelone central protective effects.

\section{CONFLICT OF INTEREST}

The authors declare that they have no competing financial interests. There is no conflict of interest for any of the authors.

\section{ACKNOWLEGMENT}

The authors gratefully acknowledge Prof. Seyed Mehdi Rezayat (Department of Pharmacology, School of Medicine, Tehran University of Medical Sciences, Tehran, Iran) for his technical advice.

\section{REFERENCES}

1. Farooqui AA, Horrocks LA, Farooqui T. Modulation of inflammation in brain: a matter of fat. $J$ Neurochem, 2007; 101:577-599. 
2. Liu NK, Xu XM. Phospholipase A2 and its molecular mechanism after spinal cord injury. Mol Neurobiol, 2010; 41:197-205.

3. Phillis JW, Horrocks LA, Farooqui AA. Cyclooxygenases, lipoxygenases, and epoxygenases in CNS: their role and involvement in neurological disorders. Brain Res Rev 2006; 52: 201-243.

4. Kumar P, Padi SS, Naidu PS, Kumar A. Cyclooxygenase inhibition attenuates 3nitropropionic acid-induced neurotoxicity in rats: possible antioxidant mechanisms. Fundam Clin Pharmacol, 2007; 21:297-306.

5. Kalonia H, Kumar P, Kumar A, Nehru B. Effect of caffeic acid and rofecoxib and their combination against intrastriatal quinolinic acid induced oxidative damage, mitochondrial and histological alterations in rats. Inflammopharmacol, 2009; 17:211-9.

6. Mello BS, Monte AS, McIntyre RS, Soczynska JK, Custodio CS, Cordeiro RC, Chaves JH, Vasconcelos SM, Nobre HV, Jr., Florenco de Sousa FC, Hyphantis TN, Carvalho AF, Macedo DS. Effects of doxycycline on depressive-like behavior in mice after lipopolysaccharide (LPS) administration. J Psychiatr Res, 2013; 47:1521-1529.

7. Ming Z, Sawicki G, Bekar LK. Acute systemic LPSmediated inflammation induces lasting changes in mouse cortical neuromodulation and behavior. Neurosci Lett, 2015; 590:96-100.

8. Casaril, A.M.; Domingues, M.; Fronza, M.; Vieira, B.; Begnini, K.; Lenardao, E.J.; Seixas, F.K.; Collares, T.; Nogueira, C.W.; Savegnago, L. Antidepressant-like effect of a new seleniumcontaining compound is accompanied by a reduction of neuroinflammation and oxidative stress in lipopolysaccharide-challenged mice. J. Psychopharmacol, 2017; 31: 1263-1273.

9. Couch, Y.; Trofimov, A.; Markova, N.; Nikolenko, V.; Steinbusch, H.W.; Chekhonin, V.; Schroeter, C.; Lesch, K.P.; Anthony, D.C.; Strekalova, T. Low-dose lipopolysaccharide (LPS) inhibits aggressive and augments depressive behaviors in a chronic mild stress model in mice. J. Neuroinflamm, 2016; 13: 108.

10. Tries, S., Neupert, W., Laufer, S. The mechanism of action of the new antiinflammatory compound ML3000: inhibition of 5-LOX and COX-1/2. Inflamm Res, 2002; 51: 135-143.

11. Koeberle A, Siemoneit U, Bühring U, Northoff H, Laufer S, Albrecht W, et al. Licofelone suppresses prostaglandin E2 formation by interference with the inducible microsomal prostaglandin E2 synthase-1. J Pharmacol Exp Ther, 2008; 326:975-82.

12. Cicero AF, Derosa G, Gaddi A. Combined lipoxygenase/cyclo-oxygenase inhibition in the elderly: the example of licofelone. Drugs Aging, 2005; 22:393-403.
13. Singh VP, Patil CS, Kulkarni SK. Anti-inflammatory effect of licofelone against various inflammatory challenges. Fundam Clin Pharmacol, 2006; 20:6571.

14. Singh VP, Patil CS, Kulkarni SK. Effect of licofelone against mechanical hyperalgesia and cold allodynia in the rat model of incisional pain. Pharmacol Rep, 2005; 57: 380-384.

15. Laufer, S. Discovery and development of ML3000. Inflammopharmacology, 2001; 9: 101-112.

16. Rotondo S, Dell'Elba G, Krauze-Brzósko K, Manarini S, Martelli N, Pecce R, Evangelista V, Cerletti C. Licofelone, a dual lipoxygenasecyclooxygenase inhibitor, down regulates polymorphonuclear leukocyte and platelet. Eur J Pharmacol, 2002; 453: 131-139.

17. Kalonia H, Kumar P, Kumar A. Licofelone attenuates quinolinic acid induced Huntington like symptoms: Possible behavioral, biochemical and cellular alterations. Prog Neuropsychopharmacol Biol Psychiatry, 2011; 35: 607-615.

18. Kraus RL, Pasieczny R, Lariosa-Willingham K, Turner MS, Jiang A, Trauger JW. Antioxidant properties of minocycline: neuroprotection in an oxidative stress assay and direct radical-scavenging activity. J Neurochem, 2005; 94: 819-827.

19. Morimoto N, Shimazawa M, Yamashima T, Nagai H, Hara H. Minocycline inhibits oxidative stress and decreases in vitro and in vivo ischemic neuronal damage. Brain Res, 2005; 1044: 8-15.

20. Kumar A, Sharma S, Prashar A, Deshmukh R. Effect of licofelone-a dual COX/5-LOX inhibitor in intracerebroventricular streptozotocin-induced behavioral and biochemical abnormalities in rats. $\mathrm{J}$ Mol Neurosci, 2014; 55:749-759.

21. Kumar A, Vashist A, Kumar P, Kalonia H, Mishra J. Potential role of licofelone, minocycline and their combination against chronic fatigue stress induced behavioral, biochemical and mitochondrial alterations in mice. Pharmacol Rep, 2012; 64: 11051115.

22. Kalonia H, Mishra J, Kumar A. Targeting neuroinflammatory cytokines and oxidative stress by minocycline attenuates quinolinic acid-induced Huntington's disease-like symptoms in rats. Neurotox Res, 2012; 22: 310-320.

23. Kim HS, Suh YH. Minocycline and neurodegenerative diseases. Behav Brain Res, 2009; 196: 168-179.

24. Dulin JN, Karoly ED, Wang Y, Strobel HW, Grill RJ. Licofelone modulates neuroinflammation and attenuates mechanical hypersensitivity in the chronic phase of spinal cord injury. J Neurosci, 2013; 33: 65264.

25. Baran H, Vass K, Lassmann H, Hornykiewicz O. The cyclooxygenase and lipoxygenase inhibitor BW755C 
protects rats against kainic acid-induced seizures and neurotoxicity. Brain Res, 1994; 646:201-206.

26. Guo R-B, Wang G-F, Zhao A-P, Gu J, Sun X-L, Hu G. Paeoniflorin protects against ischemia-induced brain damages in rats via inhibiting MAPKs/NF-jBmediated inflammatory responses. PLOS ONE, 2012; 7:e49701.

27. Banuls C, Rocha M, Rovira-Llopis S, Falcon R, Castello R, R Herance J, Polo M, Blas-Garcia A, Hernandez-Mijares A, M Victor V. The pivotal role of nitric oxide: effects on the nervous and immune systems. Curr Pharm Des, 2014; 20: 4679-4689.

28. Bredt DS, Snyder SH. Isolation of nitric oxide synthetase, a calmodulin-requiring enzyme. Proc Natl Acad Sci, 1990; 87:682-685.

29. Moncada S, Higgs E (1995). Molecular mechanisms and therapeutic strategies related to nitric oxide. FASEB J 9:1319-1330.

30. Aminirad A, Mousavi SE, Fakhraei N, Mousavi SM, Rezayat SM. The role of nitric oxide in anticonvulsant effect of nanocurcumine on pentylenetetrazole-induced seizure in mice. Neurosci Lett, 2017; 651: 226-231.

31. Yahyavi-Firouz-Abadi N, Tahsili-Fahadan P, Riazi K, Ghahremani MH, Dehpour AR. Involvement of nitric oxide pathway in the acute anticonvulsant effect of melatonin in mice. Epilepsy Res, 2006; 68:103-113.

32. Khoshnoodi M, Fakhraei N, Dehpour AR. Possible involvement of nitric oxide in antidepressant-like effect of silymarin in male mice. Pharm. Biol, 2015; 53: 739-745.

33. Salvemini D. Regulation of cyclooxygenase enzymes by nitric oxide. Cell Mol Life Sci CMLS, 1997; 53:576-582.

34. Clancy RMA, Levartovsky D, Leszczynska-Piziak J, Yegudin J, Abramson SB. Nitric oxide reacts with intracellular glutathione and activates the hexose monophosphate shunt in human neutrophils: evidence for S-nitrosoglutathione as a bioactive intermediary. Proc Natl Acad Sci, 1994; 91:36803684.

35. Clancy R, Varenika B, Huang W, Ballou L, Attur M, Amin AR, Abramson SB. Nitric oxide synthase/COX cross-talk: nitric oxide activates COX-1 but inhibits COX-2-derived prostaglandin production. $\mathrm{J}$ Immunol, 2000; 165:1582-1587.

36. Hughes FJ, Buttery LD, Hukkanen MV, O'Donnell A, Maclouf J, Polak JM. Cytokine-induced prostaglandin E2 synthesis and cyclooxygenase-2 activity are regulated both by a nitric oxidedependent and-independent mechanism in rat osteoblasts in vitro. J Biol Chem, 1999; 274:17761782.

37. Jiang X, Liu J, Lin Q, Mao K, Tian F, Jing C, Wang C, Ding L, Pang C.. Proanthocyanidin prevents lipopolysaccharide-induced depressive-like behavior in mice via neuroinflammatory pathway. Brain Res Bull, 2017; 135:40-46.

38. Bahremand A, Nasrabady SE, Ziai P, Rahimian R, Hedayat T, Payandemehr B, Dehpour AR. Involvement of nitric oxide cGMP pathway in the anticonvulsant effects of lithium chloride on PTZinduced seizure in mice. Epilepsy Res, 2010; 89:295302.

39. Payandemehr B, Bahremand A, Rahimian R, Ziai P, Amouzegar A, Sharifzadeh M, Dehpour AR. 5-HT (3) receptor mediates the dose-dependent effects of citalopram on pentylenetetrazole-induced clonic seizure in mice: involvement of nitric oxide. Epilepsy Res, 2012; 101:217-227.

40. Payandemehr B, Khoshneviszadeh M, Varastehmoradi B, Gholizadeh R, Bahremand T, Attar H, Bahremand A, Dehpour AR. A COX/5-LOX inhibitor licofelone revealed anticonvulsant properties through iNOS diminution in Mice. Neurochem Res, 2015a; 40:1819-1828.

41. Ghasemi M, Raza M, Dehpour AR. NMDA receptor antagonists augment antidepressant-like effects of lithium in the mouse forced swimming test. J Psychopharmacol, 2010; 24:585-94.

42. Kaster MP, Ferreira PK, Santos AR, Rodrigues AL. Effects of potassium channel inhibitors in the forced swimming test: possible involvement of L-argininenitric oxide-soluble guanylate cyclase pathway. Behav Brain Res, 2005; 165:204-9.

43. Porsolt RD, Bertin A, Jalfre M. Behavioral despair in mice: a primary screening test for antidepressants. Arch Int Pharmacodyn Ther, 1977; 229:327-36.

44. El Refaey H, Amri HS. Effects of antidepressants on behavioral assessment in adolescent rats. Bahrain Medical Bulletin, 2011; 33:83-9.

45. Dhingra D, Sharma A. Antidepressant-like activity of Glycyrrhiza glabra L. in mouse models of immobility tests. Prog Neuropsychopharmacol Biol Psychiatry, 2006; 30:449-54.

46. Attari M, Jamaloo F, Shadvar S, Fakhraei N, Dehpour AR. Effect of Withania somnifera Dunal Root Extract on Behavioral Despair Model in Mice: a Possible Role for Nitric Oxide. Acta Med Iran, 2016; 54:16572.

47. Steru L, Chermat R, Thierry B, Simon P. The tail suspension test: a new method for screening antidepressants in mice. Psychopharmacol, 1985; 85:367-70.

48. Mantovani M, Pértile R, Calixto JB, Santos AR, Rodrigues AL. Melatonin exerts an antidepressantlike effect in the tail suspension test in mice: evidence for involvement of N-methyl-D-aspartate receptors and the L-arginine-nitric oxide pathway. Neurosci Lett, 2003; 343:1-4.

49. Kumar P, Kalonia $\mathrm{H}$ and Kumar A. Role of LOX/COX pathways in 3-nitropropionic acidinduced Huntington's Disease-like symptoms in rats: 
protective effect of licofelone. Br J Pharmacol, 2011; 164:644-654.

50. Li CF, Chen XQ, Chen SM, Chen XM, Geng D, Liu Q, Yi LT. Evaluation of the toxicological properties and anti-inflammatory mechanism of Hemerocallis citrina in LPS-induced depressive-like mice. Biomed Pharmacother, 2017; 91:167-173.

51. Payandemehr B, Ebrahimi A, Gholizadeh R, Rahimian R, Varastehmoradi B, Gooshe M, Aghaei HN, Mousavizadeh K, Dehpour AR. Involvement of PPAR receptors in the anticonvulsant effects of a cannabinoid agonist, WIN 55, 212-2. Prog Neuropsychopharmacol Biol Psychiatry, 2015b; 57:140-145.

52. Eslami SM, Moradi MM, Ghasemi M, Dehpour AR. Anticonvulsive Effects of licofelone on status epilepticus induced by lithium-pilocarpine in Wistar rats: a role for inducible nitric oxide synthase. Epilepsy Res, 2016; 6: 53-60. 